Papaipema placida n. sp.

Head smooth on frons, antenna simple, ringed at base by white scales. The thoracic vestiture is normal in tuftings and density, dull yellowish intermixed with purple-brown; abdomen paler, lustrous luteous. Fore wing in outline rather more falcate below apex than usual; basal area defined in the dull yellow ground color, basal line double; median field evenly defined in dull yellow except above median vein inward from reinform, where a powdering of purple brown occurs; the orbicular and claviform show as three superimposed white spots, the middle one being a mere dot; the reniform is broken into dots by the veins, clustered about the central lunulate line, and all pure white except the middle outer one, which is yellow; the median shade line is prominently marked in brown from reniform to inner margin; post-medial line is double and bends outward with pronounced sweep past reniform; subterminal area dull purplish; terminal space scarcely differentiated in paler shade; the usual apical dash is of the ground colour. Hind wing much paler, of a luteous shade of the ground color of fore wing, with the veins, a discoidal spot, a median line and a subterminal band marked in brown powderings. On the under surface the wings are glistening luteous, a median line observable and brown powderings which are deepest at the costal margins.

Expanse $31 \mathrm{~mm}$.

The male genitalic structure is of the conventional pattern of the genus. In minor degree, a narrowing of the valva immediately behind the costa is noteworthy in being more pronounced than with any other species. The usual curved, and sharp-pointed harpe has its outward edge finely toothed. The unique male type is with the writer and was taken at New Brighton, Pa., (F. A. Merrick), September 6, 1907. This single example is in good condition, and unless a dwarf, indicates a small species of a coloration similar to duovata, or to occasional specimens of harrisii. From the latter and from astuta, it differs in the greater curve of the post-medial line.

\title{
NOTES ON A COLLECTION OF LABRADOR LEPIDOP'TERA.
}

BY J. MCDUNNOUGH, PH. D.*

Entomological Branch. Ottawa.

Through the kindness of Dr. E. M. Walker, of Toronto, a very interesting lot of Labrador Lepidoptera, collected in the vicinity of Hopedale, and a much smaller lot, taken at Nain, has passed through my hands for identification. Due to the long series of several species I have been enabled to clear up some doubtful points of synonymy and append herewith a list of the species collected with notes on certain of them. Where no definite locality is mentioned it is understood that the species were captured at Hopedale.

Pieris napi frigida Scud.

PIFRIDAE.

I have already on two occasions discussed the status of this race (B. \& McD., Contrib. III, 58, Pl. VII, figs. 1, 2; IV, 63). With a long series of

\footnotetext{
* Contribution from Entomological Branch, Department of Agr., Ottawa.
} 
both sexes before me, captured July 7-18, it is evident that Scudder's diagnosis was based entirely on specimens of the female sex, and rather worn specimens at that. This accounts for his statement that the "secondaries of the male frigida are shaped as in the of of oleracea" and that "the black scales above at the base of both wings are more profuse and widely spread." Borealis Grt. based on so specimens will sink as a synonym.

The underside of secondaries varies in color from quite pale to strikingly bright yellow (especially marked in $q$ 's) and in all cases the veins are very heavily outlined in black. On the upper side the $\hat{o}$ 's are pure white with the veins in the apical area marked with black; the $q$ 's have at times a marked yellow tinge, are heavily sprinkled with smoky scales on primaries at base of wing and along inner margin and in well marked specimens show traces of the two subterminal spots; the veins are more suffused with black than in the of sex. Frigida Scud. will represent the race from Labrador, Newfoundland and adjacent areas in Quebec with the partial summer generation acadica Edw. in Southern Newfoundland. The figures given in the "Contributions" (1. c. Pl. VIT, figs. 1,2) represent well-marked specimens of this race.

Eurymus pelidne labradorensis Scud.

The species was represented by a long series of rather indifferent specimens. I have treated of it in "Contributions III, 67, P1. VII, figs. 6-8." Greenland and Iceland specimens must be examined before it can be determined whether the racial name is valid or should be sunk as a synonym.

Eurymus nastes Bdv.

Two specimens, Nain.

Brenthis aphirape triclaris Hbn.

\section{NYMPHALIDAE.}

Brenthis chariclea boisduvali Dup. series.

Both the above well-known Labrador forms were represented by good

Brenthis freija Thun.

A single worn specimen, taken July 26th.

Brenthis polaris Bdv.

One of captured August 5th.

SATYRIDAE.

Oeneis jutta Hbn.

A worn $\delta$, captured on August 2 nd at Hopedale; another $\delta$ from Nain.

Oeneis taygete Hbn.

Several good specimens of both sexes captured between July 25 th and August 23rd.

Oeneis oeno Bdv.

A small series of both sexes was present.

My idea of this species was given in "Contributions IV, 68" and I still adhere to this opinion. Besides the Labrador specimens several from the north shore of the Gulf of St. Lawrence are before me, captured by C. H. Young at Rocky Bay; these cannot be separated from the Labrador specimens 
in maculation bui in the $\hat{o}$ genitalia show slight divergences and are the exact counterpart of the figure of the genitalia of katahdin given in "Contributions P1. XXX, fig. 1." Under these circumstances it would appear that katahdin should be considered as a geographical race of oeno and not as a good species. I give figures of the genitalia of the Labrador and Gulf Coast forms, the main point of distinction is found in the width of the valves at their distal end.
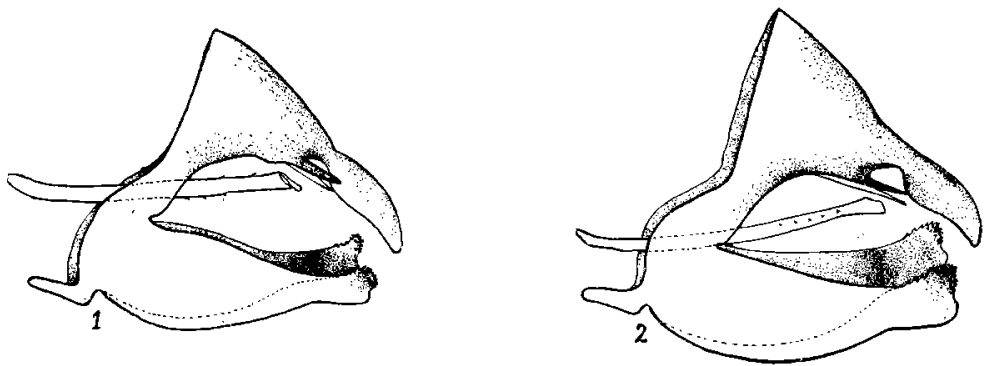

Fig. 1. Male Genitalia of Oeneis oeno Bdv. from Labrador.

Fig. 2. Male Genitalia of Oeneis oeno Bdv. from Rocky Bay.

\section{LYCAENIDAE.}

Plebeins scudderi $\mathrm{E} d w$.

As far as I know this species has not been captured in Labrador since it was recorded by Moeschler (1873, Stett. Ent. Zeitschr. 155). A small series of both sexes, taken in August, was present and the specimens are quite typical, the male showing scarcely any traces of the red submarginal funules on the underside of primaries; the $q$ is heavily shaded with blue on the upper side without or with mere traces of orange lunules above the black submarginal spots of secondaries.

Plebeius aquilo Bdv.

This well-known Arctic form was represented by a few worn specimens. Heodes dorcas Kby.

A single $q$, captured August 15 th, very closely resembles Kirby's figure in the Fauna Boreali-Americana. I am not aware that the species has been recorded from Labrador but the record is not surprising as the species is a distinctly northern one.

Hesperia centaureae Ramb.

\section{AgaristiddaE.}

Androloma mac-cullochi Kby.

Two specimens, taken July 14th and August 23rd.

NOCTUIDAE.

Epipsilia okakensis Pack.

Only a single pair of the species from Hopedale was present which is rather surprising as it is one of the commonest species in the region; a small series occurred in the lot from Nain.

Epipsilia quadrangula Zett.

A good series, illustrating the variability of the species in regard to the depth of maculation and the intensity of the black areas around the reinform and orbicular. 
Anomogyna sincera $\mathrm{H}$. S.

A single specimen without date of capture. The species has been recorded from Labrador on the authority of Moeschler, but this is the first authentic specimen which has passed through my hands. It agrees well with the figure in Spuler, Schmett. Europas. Pl. XXXIII, fig. 1.

Anarta richardsoni Curt.

One + , captured July 18th, Hopedale; several specimens from Nain. Polia pulverulenta Sm.

One 9 , captured August 6th. The record is a new one although not surprising as the type specimens were taken at Orono, Me., where so many northern forms have been located. Figures of the species will be found in the Barnes \& McDunnough Contributions, Vol. IV, P1. XVI, figs. 2, 3. Sympistis melaleuca Thun.

A good series was present: there is considerable variation in the amount of black suffusion on the primaries.

Trichoplexia exornata Moesch.

One o, captured August 5th.

Eremobia maillardi exulis Lef.

Two $\delta$ 's and one $o$ of this variable species were included in the Hopedale lot; they all belong to the form without white streaks on the veins. One specimen from Nain was also present.

Hyppa rylinoides Gn.

One ô, taken July 18 th, seems best referred to this species although the color is rather darker and the white patch above the anal angle reduced to a narrow line. More material will be necessary to determine whether we are dealing with a racial form or not.

Autographa arctica Moesch.

Of late years a few stray specimens of this species have passed througn my hands; the present collection contains a long series, however, which conclusively shows that arctica from Labrador and vaccinii $\mathrm{Hy}$. Edw. from Mt. Washington, N. H., are specifically identical. Both show the same finely waved t.p. line and vary similarly in the amount of black suffusion on the central portion of primaries.

Arctica was originally treated as a Labrador race of $u$-aureum Gn., described with type locality, Dalecarlia. Aurivillius, in his paper on the Insects of Greenland (1890, Bihang K. Sv. Vet. Akad. Hand1. XV. Afd. IV, p. 16), makes it a pure synonym of $u$-aureum along with groenlandica Staud. and figures the species on P1. 1, fig. 7. 'T'his figure corresponds remarkably closely to our Labrador specimens. Hampson (1913, Cat. Lep. Phal. Brit. Mus. XIII, 424, 432) separates u-aureum Gn. and groenlandica Staud., making vaccinii Hy. Edw. a synonym of the former and figuring the species (P1. 236, fig. 16) from a North American specimen. Under groenlandica he cites arctica Moesch. and u-aureum Auriv. (nec Gn.). His figure of groenlandica (P1. 236, fig. 23), drawn from an Iceland specimen, certainly appears to represent a species distinct from his other figure but does not agree with Aurivillius' figure above mentioned either in the shape of the gamma-mark or the wavy nature of the t.p. line. Further under u-aurcum he cites no European localities for the 
species and is followed in this by Warren in Seitz, Macrolep. Palaearc. Noct. who makes no mention of $u$-aureum as being Palaearctic. It would almost seem as if European lepidopterists had agreed that the locality 'Dalecarlia,' given by Guenée was erroneous and that the name $u$-aureum was based on Greenland or Iceland specimens; I have seen, however, no published notice to this effect.

Ottolengui (1917, Ent. News XXVIII, 29) treats of vaccinii and its synonymy but makes no mention of arctica Moesch.

The identity of u-aureum and groenlandica being in doubt I am obliged to leave them out of consideration for the present; if Aurivillius be correct Guenée's name will take priority; in the meantime the species should be known as arctica Moesch. with raccinii $\mathrm{Hy}$. Edw. as a subspecies of doubtful value from New Hampshire and possibly adjacent mountain peaks.

Syngrapha diasema borea Auriv.

A single $q$ specimen corresponds excellently well with Aurivillius' description and figure (op. cit. 17, Pl. 1, fig. 8); this race is said to differ from the type form from Northern Europe in the distinctly yellow coloration of the central area of secondaries with moderately broad smoky border. I have always been inclined to associate a form found in the Rocky Mountains of Canada with borea; this same form has recently been treated as a new species by Dr. Ottolengui (1919, Jour. N. Y. Ent. Soc. XXVII, 121, P1. XV, fig. 2) under the name diversigna. With a Paratype and a series of five males from Nordegg, Alberta, before me, I have made a careful comparison with the Labrador specimen and fail to find any characters which would warrant specific distinction; the Alberta specimens are slightly smaller and the yellow of seconiaries somewhat brighter and if desired the name diversigna Ottol. may be retained to designate the Rocky Mountain race; for the Labrador and Arctic race which is certainly easily separated from diasema by the color of the secondaries Aurivillius' term borea should be used and the synonymy would thus stand.

diasema Bdv. N. Europe.

(a) borea Auriv. Greenland, Labrador.

(b) diversigna Ottol. Canadian Rocky Mountains.

LYMANTRIIDAE.

Gynaephora rossi Curt.

One pair of this well-known Arctic form.

\section{GEOMETRIDAF.}

Acidalia frigidaria Moesch.

A series of this well-known form captured July 12th-20th shows considerable variation in the distinction of the transverse lines which at times become almost lost in the general gray ground-color.

Carsia paludata labradoriata Moesch.

One specimen.

Dy.sstroma citrata Linn.

A couple of rather worn specimens taken 23rd August. These were of the dull gray form with slight ruddy subterminal suffusion and with median band rather paler than the remainder of the wing, due to less heavy sprinkling of gray scales. This appears to be the usual form in northern localities. 
Xanthorhoe designata Hufn.

A small series, rather worn, captured between July 25th and August 6th. Xanthorhoe algidata Moesch.

The identity of this species has always been doubtful; the general conception, following a specimen in the British Museum, is that it is a species closely allied to fossoria Tayl. A single of before me fits these requirements although not agreeing very closely with the original description as regards the details of the median band. For the present I identify it tentatively as algidata. The genitalia seem distinct from those of the other members of the group as far as I can judge from Swett's paper (1918, Can. Ent. L, 17) with little or no material before me for comparison. The costa is narrow apically and bears a bunch of long spines directed inward.

Xanthorhoe ferrugata Clerck.

A number of specimens captured in July and considerably the worse for wear.

Euphyia luctuata obductata Moesch.

Apparently one of the commonest geometers of this region; some specimens show traces of a narrow pale band on secondaries.

Eulype hastata Linn.

One specimen, taken August 5th, of the typical form.

Dasyuris polata Dup.

Two $\odot$ 's, captured August 21st and 22nd.

Eupithecia sp.

Several specimens too worn for identification.

Macaria granitata sexmaculata Pack.

Four specimens which presumably may be referred to this race. Aspilates orciferaria labradoriata Moesch.

A good series, the $q$ 's showing a decided yellowish tinge to the primaries

Nomophila noctuclla Schiff.

$$
\text { PyratidDAF. }
$$

Two specimens taken early in August.

Scoparia centuriella Schiff.

A number of small, rather dark specimens.

Laodamia fusca Haw.

One male.

Platyptilia carduidactyla Riley.

Two specimens of this species, kindly identified for me by Dr. A. Lindsey; the species has to my knowledge not been previously recorded from Labrador.

\section{GELECHIIDAE.}

Gelechia continuella Zell.

One specimen. This European species has been twice described from North America under the names trimaculella Pack. and albamaculella Cham. Mr. A. Busck informs me that he has recently made slides of the $\hat{o}$ genitalia of specimens from both continents and they prove to be identical, establishing the above synonymy. 


\section{TORTRICIDAE.}

Olethreutes intermistana Clem.

Three specimens; kindly identified by Mr. A. Busck of the U. S. National Museum.

Tortrix moeschleriana Wocke.

Two specimens.

Cnephasia osseana Scop.

Three specimens; identified by Mr. A. Busck.

TINEIDAF.

Monopis biflarimaculella Clem.

Four specimens.

\section{CRAGIN'S COLLEC'TION OF KANSAS MYRIAPODA. \\ BY HORACE GUNTHORP, \\ University of Washington, Seattle, Wash.}

The first Myriapod record for the State of Kansas is that of Wood (8, pg. 11 $)^{1}$, who reported the single form Scolopendra polymorpha from Fort Riley, Kansas, in 1861. This constituted the sole record for the state until 1885, when Meinert (7, pg. 196) reported Scolopendra heros from Riley, Kans. As he considered $S$. polymorpha a synonym of $S$. heros, forms now known to be distinct, he was undoubtedly dealing with the former, as there is no authentic record of $S$. heros occurring as far north in Kansas as Fort Riley, so he cannot be said to have added a new name to the state list. The same year W. F. Cragin (5) published a short list of Kansas Myriapoda in which he enumerated twelve forms covering some nine species in seven genera. In 1893, Bollman (2, pg. 183) placed Parajulus venustus on the Kansas list.

No new forms were added until 1913, when the present writer published a more extended catalogue, covering more extensive collecting over the state. This latest list included a total of fourteen species of Diplopoda and fifteen of Chilopoda.

At the time of publishing this last mentioned paper, an effort was made to examine the collection evidently made by Professor Cragin, with the result therein recorded (6, pg. 168) which was as follows: "Through the kindness of Prof. C. H. Edmundson, of Washburn College, I have examined two individuals of this species (Scolopendra heros) collected by Cragin in Barber County. The larger one measures $140 \mathrm{~m}$. These two specimens are all that remain of Prof. Cragin's Myiapoda collection, as the remainder were destroyed by fire." This fire occurred in 1908.

During the past year, while the writer was rearranging the specimens in the museum at Washburn College, a perforated board holding some fifty bottles of specimens came to light, some of which, upon examination, proved to be part of the Myriapoda collected by Cragin. This led to a systematic search of the laboratories and store rooms, with the result that a total of twenty bottles plus one dried, pinned specimen were found. With the exception of the latter, there is little doubt but that they are all from one original collection, in

1Numbers in parenthesis refer to bibliography at end. 